\title{
Seasonal variations of Red Deer selectivity on a mixed forest edge
}

\author{
Bertrand DUMONT ${ }^{\mathrm{a} *}$, Pierre-Cyril RENAUD ${ }^{\mathrm{a}}$, ${ }^{\mathrm{b}}$, Nicolas MORELLET $^{\mathrm{b}}$, \\ Christophe MALLET $^{\mathrm{a}}$, Frederic ANGLARD ${ }^{\mathrm{a}}$, Hélène VERHEYDEN-TIXIER ${ }^{\mathrm{b}}$
}

a INRA, Unité de Recherches sur les Herbivores, Theix, 63122 Saint-Genès-Champanelle, France
b INRA, Comportement et Écologie de la Faune Sauvage, BP 27, 31326 Castanet-Tolosan, France

(Received 4 November 2004; accepted 18 April 2005)

\begin{abstract}
Red deer play a major role in shaping forest vegetation, and a better understanding of their selectivity is needed in order to provide a basis for deer habitat and population management. In order to measure deer selectivity, information is required on both the use and availability of different food items at the feeding site scale, which has often been proven difficult to achieve with wild animals. In this study, we introduced three hinds for five days in each season into a 1 ha paddock established on a mixed forest edge. We analysed the relationship between the choices made on the first day in the paddock and the available vegetation, and calculated selectivity indexes $\left(\mathrm{S}_{\mathrm{j}}\right)$. The hinds were highly selective, with on average $82 \%$ of their diet made of preferred species. Selected and avoided species varied between seasons according to plant phenology, except for conifers and ferns, which were always avoided. The intermediate feeding style of the Red Deer was confirmed, with concentrate foods (broad-leaved trees and seedlings, shrubs, forbs and legumes) being selected from the spring to the autumn, followed by a switch to grass during the winter. The hinds selected grass in the winter since it was a highly available and relatively "high quality" forage at that time. The net intake of digestible energy was probably increased by eating grass than by searching for the higher quality but scarce forbs. This resulted in the dry matter intake maximisation hypothesis being valid during the winter, but rejected for the other seasons. The highly selective consumption of broadleaved seedlings throughout the growing season suggests a high risk of damage to these seedlings at a year-round deer density of about 15 hinds per $\mathrm{km}^{2}$.
\end{abstract}

Cervus elaphus / diet selection / Jacobs index / seasonal variations / vegetation sampling technique

Résumé - Variations saisonnières de la sélectivité du cerf élaphe en milieu forestier. Mieux connaître la sélectivité alimentaire du cerf élaphe est nécessaire pour pouvoir gérer ses populations et limiter ses dégâts en milieu forestier. Ceci nécessite de mesurer simultanément ses choix et les disponibilités alimentaires, ce qui est particulièrement difficile en milieu naturel. Ici, nous avons observé les choix alimentaires de trois biches dans un enclos d'un hectare établi en lisière de forêt, que nous avions préalablement caractérisé et cartographié. Nous rapportons les choix réalisés à

* Corresponding author: dumont@clermont.inra.fr 
chaque saison lors de la première journée dans l'enclos, et calculons pour chaque espèce un indice de sélection $\left(\mathrm{S}_{\mathrm{i}}\right)$ en reliant le prélèvement des animaux aux disponibilités alimentaires. Les biches ont été très sélectives avec en moyenne $82 \%$ de leur régime composé d'espèces préférées. Elles ont sélectionné des espèces différentes au cours de l'année, seuls les conifères et les fougères étant systématiquement évités. La classification du cerf parmi les « intermediate feeders » a été vérifiée ici, puisque les biches ont, du printemps à l'automne, sélectionné les feuillus, les ligneux bas à feuilles caduques et au sein du couvert herbacé les dicotylédones, et se sont principalement reportées sur les graminées en hiver. La sélection des graminées pendant l'hiver s'explique parce qu'elles représentent alors une ressource fortement disponible et de valeur nutritive relativement élevée en comparaison des autres aliments. Le flux d'énergie ingéré est probablement supérieur à celui qui résulterait de la sélection des dicotylédones, de meilleure valeur nutritive mais rares. L'hiver est ainsi la seule saison où un modèle de maximisation de l'ingestion permet de décrire le prélèvement des animaux. Enfin, la forte sélection des petits plants de feuillus durant toute la période de végétation laisse présager que leur régénération naturelle est difficile à une densité annuelle de 15 biches au kilomètre carré.

Cervus elaphus / estimation de la phytomasse / indice de Jacobs / sélection alimentaire / variations saisonnières

\section{INTRODUCTION}

Red deer (Cervus elaphus L.) populations are increasing rapidly in parts of Northern Europe and America, causing damage to forestry and agriculture $[45,54]$. In forests, deer play a major role in shaping vegetation dynamics through selective consumption of particular plants or plant communities, and through bark stripping. The impact of herbivores on forest resources and their spatial distribution can be directly recorded, but it then becomes difficult to evaluate the species and number of herbivores that have caused this damage [40]. A better understanding of the diet selection process is therefore needed in order to construct predictive models of plant use and impact, and provide a basis for deer habitat and population management [22].

The diet consumed by the red deer and its seasonal variations have been described for various geographic areas, and the differences in the foods eaten usually reflect the relative abundance of the plant species in these habitats $[5,16,51]$. However, the majority of field studies have used either rumen content analyses [21, 35, 48, 56] or microhistological identification of plant epidermal fragments in faecal material $[5,20$, $24,30,44]$, underestimating highly digestible forages and overestimating fibrous forages. Moreover, knowledge of diet com- position does not allow quantification of food selection, which requires information on both the use and the availability of the different food items at the feeding site scale. This is constrained by the animals' mobility, since in the course of two days (i.e., the maximum food retention time for the red deer, [32]) the animals can roam over distances of several kilometres and use several habitats. Consequently, diet composition measurements have usually only been related to a brief description of the main plant species present and of their abundance in the area studied. Also, even when using radiocollared animals $[11,53]$, it remains difficult to accurately quantify the biomass that the animals selected. Studies of the winter diet by tracking feeding deer in the snow and recording the shoots browsed along their journey $[10,34,50]$ can be constrained by difficulties in assigning tracks to deer species and correctly identifying the time of browsing on each browsed twig.

Thus, despite the lists of consumed or avoided plant species [14] and short-term preference measurements between species $[6,49]$ or sapling structures $[23,46]$, there are still very few measurements of food selection by the red deer within a forest habitat. The existing studies generally faced the above-mentioned limitations, and were conducted for only one season $[11,31,34,53]$. In this study, we aimed at obtaining precise 
measurements of both forage availability and red deer diet composition over a whole year. We thus used direct observation to quantify the choices made by three tame hinds foraging within a well-characterised forest-edge paddock, which we discuss in relation to the general patterns reported in the literature. By relating diet choices to available vegetation, we were able to calculate and discuss selection indexes for some of the major broad-leaved tree species in temperate forests.

\section{MATERIALS AND METHODS}

\subsection{Animals}

The experiment was conducted at the INRA farm at Redon $\left(45^{\circ} 42^{\prime} \mathrm{N}, 03^{\circ} 30^{\prime} \mathrm{E}\right.$; altitude $680 \mathrm{~m}$; annual rainfall $700 \mathrm{~mm}$ ). We used three tame adult red deer hinds born on the farm, weighing an average 118 (SD: $8) \mathrm{kg}$, and with shoulder heights between 1.00 and $1.03 \mathrm{~m}$. The animals were introduced into a 1 ha observation paddock established on a mixed forest edge for five consecutive days in October 2000 (autumn), February 2001 (winter), May 2001 (spring) and July 2001 (summer), thereby simulating a year-round deer density of about 15 hinds per $\mathrm{km}^{2}$. There was no snow cover on the ground during any of the observation periods. The animals were habitually grazed on pastures but had periodically browsed trees and shrubs during their lifetime. They were reaccustomed to browsing before each observation period, being kept for at least three weeks in a mixed forest paddock, adjacent to the observation paddock and similar in vegetation. Three weeks exceeds the period of approximately one week during which diet selection has been shown to be affected by previous feeding regime in ruminants [19]. The animals were selected from an initial group of six after a 10-day preliminary period in September 2000, during which the foraging activity and food items consumed (broad-leaved trees, brambles, broom or herbaceous layer) by each animal were recorded every 3 min from dawn to dusk on four occasions in the adjacent paddock. The three animals were selected to account for the observed variability in broad-leaved tree consumption: Hind 001 spent $11 \%$ of its foraging time on broad-leaved trees, versus 5 and $1 \%$ for hinds 006 and 018, respectively. As from the second observation period in the winter, hind 018 had become reluctant to accept the close presence of the observer, so it was replaced by hind 013 , which had registered the second lowest score for tree consumption, at $2 \%$.

\subsection{Paddock}

We used a total of 300 systematic pointquadrats on 30 fixed $20 \mathrm{~m}$-long transects (one measurement every $2 \mathrm{~m}$ ) in order to provide a measurement of the relative abundance of plant species and sward types in the paddock. Standardised methods have been widely used to estimate sward [9] or shrub [12] biomass and composition, but the difficulty here was to estimate edible vegetation biomass simultaneously in herbaceous, shrub and tree layers. We therefore used a recently validated method [47] that uses a 2 m-high metallic squared column with a $25 \times 25 \mathrm{~cm}$ base, since red deer with shoulder height between 82 and $105 \mathrm{~cm}$ have never been shown to browse higher foliages [46]. The column was graduated at $20 \mathrm{~cm}$ intervals. At each transect point, the number and nature of the contacts between edible vegetation (green leaves, sprouts, buds and fruits) and the metallic structure were counted between two successive increments. At the same time, we constructed an abacus for each tree or shrub species and each sward type in order to link the number of contacts with the metallic structure to vegetation biomass in a $25 \times 25 \times 20 \mathrm{~cm}$ volume. Vegetation samples were therefore taken from the adjacent paddock at each season, with 426 samples (median: 20, range: 4-23 per food item) made in the autumn, $315(15,5-$ $20)$ in the winter, $396(15,5-20)$ in the spring and $396(15,9-20)$ in the summer. 


\subsection{Behaviour measurements}

At each season, the animals were continuously observed from dawn to dusk on the first, third and fifth days in the paddock. This paper reports the choices made on the first day, which can be related to the available vegetation in order to assess the selectivity of deer for some of the major species in temperate forests. Observations over the whole daylight period were preferred to simple snapshots during the main grazing periods, since deer can select very different foods in successive bouts [18] and follow diurnal selection patterns [7]. As in previous direct observations of tame deer [18,26, 55], several days were set aside before each observation period in order to get the animals accustomed to the close and continuous presence of the observer. Three observers participated in the study, each staying within 2 to $5 \mathrm{~m}$ of one of the animals, following it in a non-directive manner and recording with a microphone the times of transition between feeding, walking, bark stripping, drinking, ruminating, standing, lying and grooming. The plants consumed were identified as tree, shrub or seedling species. For the herbaceous layer, observers recorded not only the botanical composition of the bites taken (grass, legumes or forbs), but also whether these bites were pure (more than $90 \%$ of the bite on either grass, legumes or forbs) or mixed (with the dominant botanical item being identified). Bites on ferns (Pteris aquilina) were recorded separately. When an animal selected chestnuts, acorns, blackberries or cherries, the number of fruits consumed was counted. When an animal was observed bark stripping, the tree species was identified, and the area of bark removed was estimated.

In order to convert feeding times to intake, the biting rates and bite weights obtained on different food items were estimated by each observer for their animal during the same week. Biting rates on the different plant species or sward types were counted for one minute at several occasions, and bite weight was estimated by taking grab samples sim- ulating the eating behaviour of the animals $[26,42,57]$. These samples were ovendried at $80^{\circ} \mathrm{C}$ for $48 \mathrm{~h}$ in order to estimate their dry matter content, and their in-vitro dry matter digestibility (DMD) was measured using the pepsin-cellulase method ([2], Tab. I), since DMD is considered a rough but synthetic index of relative forage quality. For each plant species or sward type, the biting rate and bite weight were then multiplied to give the intake rate as the dry matter ingested per unit of time. The intake rate was then multiplied by the feeding time in order to give the dry matter intake on each plant species or sward type during daylight hours. Bites within the herbaceous layer were converted into the intake of either grass or forbs and legumes, with mixed bites considered as constituting $70 \%$ of the dominant botanical item (e.g. mixed-forb bites were considered to constitute $70 \%$ forbs and legumes and $30 \%$ grasses).

Diet selection, defined as the proportion of a plant species or sward type in the diet relative to its proportion in the paddock, was quantified by calculating selectivity indexes $\left(\mathrm{S}_{\mathrm{i}}\right)$ for each vegetation component using Jacobs' modification [33] of Ivlev's electivity index, as follows:

$\mathrm{S}_{\mathrm{i}}=\left(\mathrm{c}_{\mathrm{i}}-\mathrm{a}_{\mathrm{i}}\right) /\left(\mathrm{c}_{\mathrm{i}}+\mathrm{a}_{\mathrm{i}}-2 \mathrm{c}_{\mathrm{i}} \mathrm{a}_{\mathrm{i}}\right)$, where $\mathrm{c}_{\mathrm{i}}$ is the proportion (between 0 and 1 ) of component $i$ in the diet, and $\mathrm{a}_{\mathrm{i}}$ the proportion (between 0 and 1 ) of component $i$ in the paddock. $S_{\mathrm{i}}$ varies from -1 (never used) to +1 (exclusively used), with negative and positive values indicating avoidance and selection, respectively, and 0 indicating that a plant component is used in proportion to its availability. The Jacobs' index was chosen for its low sensitivity to variations in the relative abundance of plant components, thus enabling the ranking of abundant and rare plant species according to their acceptability for the animals. At each season, we considered that a food item was selected if the mean - s.e.m. was positive, and that a food item was avoided if the mean + s.e.m. was negative. This method was preferred to the 
Table I. Dry matter digestibility (DMD) of the main food items in each season, estimated from grab samples simulating the selective behaviour of the animals, and ranked in 5\% range classes. DMD was considered a rough but synthetic index of relative forage quality.

\begin{tabular}{lcccc}
\hline Digestibility $(\%)$ & Spring & Summer & Autumn & Winter \\
\hline$[80 ; 85[$ & $R c ;$ Ps; $P A v ;$ forbs & $P A v$ & & \\
{$[75 ; 80[$} & $S s$ & $P s ; f o r b s$ & & \\
{$[70 ; 75[$} & $R f$ & $R c ; R f$ & $R c$ & \\
{$[65 ; 70[$} & grass & $S C$ & $f o r b s ; P A v ; P s$ & \\
{$[60 ; 65[$} & $B A ; A P ; C A$ & & $S C$ & forbs; Ss \\
{$[55 ; 60[$} & $Q P ; S C$ & & $R f ; S s ; Q P$ & \\
{$[50 ; 55[$} & $P A b$ & $Q P ; C A ; S s ;$ grass & $B A$ & $R f ;$ grass; $R c$ \\
{$[45 ; 50[$} & & $B A$ & $C A$ & $P A b ; A P$ \\
{$[40 ; 45[$} & & $A P ; P A b$ & grass; $P A b ; A P$ & $P A v ; S C$ \\
{$[35 ; 40[$} & & & $Q P$ \\
{$[30 ; 35[$} & & & & $B A ; C A$ \\
{$[25 ; 30[$} & & & & $P s$ \\
{$[20 ; 25[$} & & & & \\
\hline
\end{tabular}

AP: Silver-fir (Abies pectinata); BA: Birch (Betula alba); CA: Common hazel (Corylus avellana); $P A b$ : Norway-spruce (Picea abies); PAv: Wild cherry (Prunus avium); Ps: Blackthorn (Prunus spinosa); QP: Oak (Quercus pedunculata); Rc: Dog rose (Rosa canina); Rf: Bramble (Rubus fructicosus); SC: Willow (Salix caprea); Ss: Broom (Sarothamnus scoparius).

use of arbitrary thresholds, as done by Fraser and Gordon [15].

\subsection{Data analyses}

In order to convert the number of contacts with the metallic structure into vegetation biomass measurements, we built four models, one for each season, taking into account plant species, number of contacts, and the interaction between these two factors in a general linear model (GLM procedure, [52]). These models accounted for $84 \%$ to $92 \%$ of total variance. Since variance increased with mean, resulting in a significant overdispersion for general linear models (values between 1.6 and 5.8), we finally opted for a generalised linear model (GENMOD procedure, [52]) with a Poisson distribution, using the natural logarithm as the link function [39]. These Poisson regressions provide a method to control overdispersion (new values between 0.49 and 0.95 ) and should account for the major proportion of the total variance.
A meal was defined as a feeding period of at least $5 \mathrm{~min}[13,18]$ without an interruption of over $1 \mathrm{~min}$ for lying down or rumination or $10 \mathrm{~min}$ for walking, standing or drinking [8]. We used a non-parametric Cochran-Mantel-Haenszel test (FREQ procedure, [52]) in order to investigate seasonal variations in the number of meals during daylight hours and in the duration of these meals, while controlling for the hind (this test is a generalisation of the Friedman test for treatment differences in a non-randomised complete block design).

We also used a Cochran-Mantel-Haenszel test, controlling for food items, in order to compare the contribution of broad-leaved trees and seedlings, brambles and grasses in the winter diet (in \%DM intake during daylight hours) with those of the other seasons. We used the same test to detect seasonal variations in the selectivity of animals $\left(\mathrm{S}_{\mathrm{i}}\right)$ for the main vegetation components, one on deciduous-leaved species (broad-leaved trees and seedlings, dog-rose, blackthorn, broom) and another on evergreen species (conifers, 
Table II. Details of the contribution of the main plant species to edible vegetation biomass (in $\%)$. Only the live material in the litter and live ferns were considered as edible to the animals. Other broad-leaved (BL) trees: Aria nivea, Fraxinus excelsior and Sambucus nigra. Other shrubs: Ribes rubrum, Crataegus oxyacantha, Vitis vinifera and Rubus idaeus. $\varepsilon$ indicates that the item was present but contributed to less than $0.05 \%$ of edible biomass.

\begin{tabular}{|c|c|c|c|c|}
\hline $\begin{array}{l}\text { Contribution } \\
\text { to biomass }(\%)\end{array}$ & Spring & Summer & Autumn & Winter \\
\hline Willow & 0.4 & 0.3 & 0.3 & 0.1 \\
\hline Wild cherry & 1.0 & 1.0 & 0.3 & 0.1 \\
\hline Chestnut tree & 0.1 & 0.4 & 0.2 & 0.2 \\
\hline Rowan & 0.5 & 0.1 & 0.2 & $\varepsilon$ \\
\hline Common hazel & 0.4 & 1.0 & 0.6 & 0.5 \\
\hline Oak & 0.7 & 1.8 & 1.3 & 0.9 \\
\hline Birch & 0.2 & 0.3 & 0.3 & 0.2 \\
\hline Beech & 0.2 & 0.2 & 0.3 & 0.1 \\
\hline Other BL trees & $\varepsilon$ & 0.2 & $\varepsilon$ & $\varepsilon$ \\
\hline $\begin{array}{l}\text { Wild cherry } \\
\text { seedlings }\end{array}$ & 2.0 & 1.6 & 0.3 & 0.5 \\
\hline $\begin{array}{l}\text { Other BL } \\
\text { seedlings }\end{array}$ & 0.8 & 1.0 & 1.0 & 0.4 \\
\hline Coniferous trees & 17.2 & 8.5 & 8.5 & 22.0 \\
\hline $\begin{array}{l}\text { Coniferous } \\
\text { seedlings }\end{array}$ & 2.5 & 1.6 & 1.1 & 2.1 \\
\hline Dog rose & 1.5 & 0.9 & 0.5 & 0.4 \\
\hline Broom & 31.2 & 18.2 & 17.1 & 19.3 \\
\hline Brambles & 11.7 & 17.0 & 7.7 & 8.4 \\
\hline Blackthorn & 1.4 & 1.4 & 0.5 & 1.2 \\
\hline Other shrubs & 0.4 & 0.3 & 0.3 & $\varepsilon$ \\
\hline Ivy & 1.8 & 0.9 & 0.9 & 0.8 \\
\hline Grasses & 16.5 & 29.2 & 41.7 & 39.9 \\
\hline Forbs, Legumes & 8.6 & 8.8 & 6.5 & 2.9 \\
\hline Fruits & 0 & $0.1^{*}$ & $1.3^{* *}$ & 0 \\
\hline Ferns & 0.9 & 5.2 & 2.9 & $\varepsilon$ \\
\hline Fallen leaves & 0 & 0 & 6.2 & 0 \\
\hline $\begin{array}{l}\text { Total edible } \\
\text { biomass } \\
\text { (t DM per ha) }\end{array}$ & 2.2 & 3.8 & 3.7 & 1.6 \\
\hline
\end{tabular}

*: Cherries; **: Chestnuts and acorns. brambles, ivy, grasses, forbs and legumes). We then used a Kruskal-Wallis test (NPAR1WAY procedure, [52]) to provide deeper analysis into seasonal variations in selectivity for certain food items.

Finally, we compared the consumption of each vegetation component, i.e. the actual diet, with 1000 simulated random diets obtained by permuting the time spent eating each plant species within the actual sequences. These random diets were simulated with a computer program using SAS Macro Language Software [52]. We ensured that each random diet was realistic; a plant could not be consumed more than its absolute available biomass in the paddock. Comparing actual and randomly-simulated diets (time spent feeding $\times$ intake rate) allowed us to identify the food items being eaten more than they are randomly encountered, which is another means of identifying selected food items. The same analysis made on dry matter intake during daylight hours enabled us to test for an intake maximisation hypothesis. We considered the number of permutations in which the intake of a food item or dry matter intake during daylight hours was higher than that in the actual diet in order to estimate the significance of the effect, i.e. if less than 50 of these 1000 simulated intakes were higher than that in the actual diet, the hypothesis was accepted with a $5 \%$ risk of error.

\section{RESULTS}

Edible vegetation biomass was $2.2 \mathrm{t} \mathrm{DM}$ per ha in the spring, $3.8 \mathrm{t} \mathrm{DM}$ per ha in the summer, 3.7 $\mathrm{t} \mathrm{DM}$ per ha in the autumn and $1.6 \mathrm{t} \mathrm{DM}$ per ha in the winter. The main broad-leaved trees in the paddock were oak (Quercus pedunculata [3], see Tab. II for seasonal variability), wild cherry (Prunus avium), common hazel (Corylus avellana), birch (Betula alba), willow (Salix caprea), chestnut tree (Castanea vulgaris), beech (Fagus sylvatica) and rowan (Sorbus aucuparia). The main coniferous trees were silver-fir (Abies pectinata: $6 \%$ of biomass 
on average), Norway-spruce (Picea abies: $4.5 \%$ ) and Nordmann fir (Abies nordmanniana: $3 \%$ ). The more common seedlings were natural regeneration of silver fir $(1.7 \%)$, wild cherry $(1.1 \%)$, oak $(0.2 \%)$, Norway spruce $(0.15 \%)$ and willow $(0.1 \%)$. The main shrubs were broom (Sarothamnus scoparius, Tab. II), bramble (Rubus fructicosus), blackthorn (Prunus spinosa) and dog rose (Rosa canina).

There were seasonal variations in the number of meals taken by hinds during the daylight hours $\left(\mathrm{Q}_{3}=7.5 ; \mathrm{n}=12 ; P=0.05\right)$ and in the duration of these meals $\left(\mathrm{Q}_{3}=\right.$ $12.1 ; \mathrm{n}=86 ; P<0.01)$. There were fewer meals in the winter (5.0 meals on average), spring (6.0) and autumn (6.3) than in the summer (11.3). Summer meals were also shorter (37 min on average) compared to those taken in the winter ( $86 \mathrm{~min})$, spring (72 min) and autumn (62 min).

Table III shows how the diet composition varied between the seasons. Deer consumed $30-40 \%$ of their diet on broadleaved trees and seedlings during the growing season but less than $1 \%$ of this diet in the winter $\left(\mathrm{Q}_{1}=5.4 ; \mathrm{n}=12 ; P<0.05\right)$, while the consumption of grasses and brambles peaked in the winter $\left(\mathrm{Q}_{1}=5.4 ; \mathrm{n}=12\right.$; $P<0.05)$. Conifers were almost never used. The main forb and legume species consumed were Plantago lanceolata [3], Gallium spp., Taraxacum dens-leonis, Vicia cracca and Trifolium repens.

Table IV shows Jacobs' indexes $\left(\mathrm{S}_{\mathrm{i}}\right)$ for the main vegetation components for each season. Preferred species (mean - s.e.m. $>0$ ) accounted for between $72 \%$ and $95 \%$ of daily intake according to season ( $82 \%$ on average). There was an overall seasonal pattern with deciduous-leaved species being selected during the growing season and avoided in the winter $\left(\mathrm{Q}_{3}=37.7 ; \mathrm{n}=132\right.$; $P<0.0001$ ), and evergreen species usually being selected more in the winter than in the other seasons $\left(\mathrm{Q}_{3}=18.9 ; \mathrm{n}=72 ; P<0.001\right)$. The Kruskal-Wallis test confirmed significant $(P<0.05)$ seasonal variations in selectivity for willow and dog rose (selected throughout the growing season), beech (selected in the spring), broom (selected in the summer), and grasses and brambles (selected in the winter). Selectivity for oak ranged from -0.83 in the summer to 0.22 in the spring $(P<0.10)$.

The comparison of actual and simulated diets led to the validation of the intake maximisation hypothesis for each animal during the winter; Hind 001: actual 2.12 vs. simulated range [1.98-2.14] $\mathrm{kg}(P<0.05)$, Hind 006: 1.53 vs. [1.33-1.51] $\mathrm{kg}(P<0.001)$, Hind 013: 1.55 vs. [1.39-1.56] kg $(P<0.001)$, but not for the other seasons. Table $\mathrm{V}$ shows the food items being eaten more than randomly encountered for each season. The hinds selected dog rose, beech and redcurrant (Ribes rubrum) in the spring, willow and dog rose in the summer and autumn, and grasses in the winter.

\section{DISCUSSION}

The Red Deer is usually classified amongst the intermediate feeders [28, 29], which choose a mixed diet with concentrate foods (browse, forbs, fruits) and grasses, and adapt to seasonal changes in the quantity and quality of food by altering the composition of their diet. It is predicted that intermediate feeders avoid fibre for as long and as much as possible, and should therefore select concentrate foods when overall browse quality and availability are high. When the availability of concentrate foods declines (i.e. in the winter for temperate climates), deer should trade-off intake and diet quality, and eventually switch to a grassbased diet, especially since their intermediately high ratio of rumen to body mass allows them to digest the cellulose content in grass reasonably well, at least better than the highly lignified browse twigs.

On this mixed forest edge, the choices made by the three hinds matched these predictions perfectly. Seasonal variations in diet composition were very clear, with a main opposition between the winter and the 
Table III. The effects of season on deer diet (details of the contribution of the main food items to intake in \% of D1 diurnal intake). Data are averaged for the three hinds. S.e.m. allow to assess the magnitude of variation between individual animals. Bold characters are for food items representing more than $10 \%$ of diurnal intake. $\varepsilon$ indicates that the item was consumed but contributed to less than $0.05 \%$ of intake. Other broad-leaved (BL) trees: Aria nivea, Fraxinus excelsior and Sambucus nigra. Other shrubs: Ribes rubrum, Crataegus oxyacantha, Vitis vinifera and Rubus idaeus.

\begin{tabular}{|c|c|c|c|c|}
\hline Mean on Day 1 (s.e.m.) & Spring & Summer & Autumn & Winter \\
\hline Willow & $3.7(1.3)$ & $16.9(0.4)$ & $21.9(0.8)$ & $0.1(0.1)$ \\
\hline Wild cherry & $1.6(0.4)$ & $2.0(0.5)$ & $3.6(1.9)$ & $0.1(0.1)$ \\
\hline Chestnut tree & $0.8(0.5)$ & $2.7(1.3)$ & $1.9(0.7)$ & $0.0(0.0)$ \\
\hline Rowan & $2.4(1.1)$ & $0.5(0.1)$ & $0.7(0.5)$ & $0.0(0.0)$ \\
\hline Common hazel & $0.6(0.1)$ & $1.9(1.0)$ & $0.9(0.3)$ & $0.1(0.0)$ \\
\hline Oak & $1.2(0.4)$ & $0.2(0.0)$ & $0.5(0.2)$ & $0.5(0.2)$ \\
\hline Birch & $0.2(0.1)$ & $0.1(0.0)$ & $0.9(0.7)$ & $0.0(0.0)$ \\
\hline Beech & $1.0(0.2)$ & $0.0(0.0)$ & $0.0(0.0)$ & $\varepsilon(0.0)$ \\
\hline Other BL trees & $0.3(0.1)$ & $0.8(0.1)$ & $0.5(0.2)$ & $0.0(0.0)$ \\
\hline BL seedlings & $18.4(4.2)$ & $14.3(6.5)$ & $10.7(2.4)$ & $\varepsilon(0.0)$ \\
\hline Coniferous trees & $0.0(0.0)$ & $0.0(0.0)$ & $0.0(0.0)$ & $0.2(0.1)$ \\
\hline Conif. seedlings & $0.0(0.0)$ & $0.0(0.0)$ & $0.0(0.0)$ & $0.0(0.0)$ \\
\hline Dog-rose & $\mathbf{1 7 . 5}(1.8)$ & $11.7(2.4)$ & $20.8(2.6)$ & $0.0(0.0)$ \\
\hline Broom & $8.1(1.2)$ & $30.6(6.8)$ & $0.1(0.0)$ & $0.6(0.5)$ \\
\hline Brambles & $2.0(0.4)$ & $0.2(0.1)$ & $1.3(0.1)$ & $14.2(2.5)$ \\
\hline Blackthorn & $1.3(0.5)$ & $4.7(2.2)$ & $1.8(0.7)$ & $0.0(0.0)$ \\
\hline Other shrubs & $1.0(0.1)$ & $0.2(0.2)$ & $\varepsilon(0.0)$ & $\varepsilon(0.0)$ \\
\hline Ivy & $0.4(0.3)$ & $\varepsilon(0.0)$ & $0.0(0.0)$ & $2.2(1.0)$ \\
\hline Grasses & $13.3(2.1)$ & $3.2(1.2)$ & $15.7(3.7)$ & $75.5(3.0)$ \\
\hline Forbs, Legumes & $25.4(2.8)$ & $9.5(2.9)$ & $17.1(1.8)$ & $5.0(1.1)$ \\
\hline Fruits & $0.0(0.0)$ & $0.5(0.4)$ & $0.3(0.2)$ & $\varepsilon(0.0)$ \\
\hline Bark & $0.6(0.1)$ & $\varepsilon(0.0)$ & $\varepsilon(0.0)$ & $0.7(0.1)$ \\
\hline Ferns & $0.0(0.0)$ & $0.0(0.0)$ & $0.0(0.0)$ & $0.0(0.0)$ \\
\hline Fallen leaves & $0.0(0.0)$ & $\varepsilon(0.0)$ & $1.6(1.1)$ & $0.7(0.2)$ \\
\hline $\begin{array}{l}\text { Intake (kg DM) during } \\
\text { daylight }\end{array}$ & $1.41(0.35)$ & $2.05(0.08)$ & $1.42(0.18)$ & $1.86(0.23)$ \\
\hline
\end{tabular}

three other seasons (Tabs. III-V). The proportion of grasses in the hinds' diet decreased between the spring and the summer (Tab. III) in line with grass nutritive value (Tab. I), and as also predicted by Hofmann [29], the hinds took more but shorter meals in the summer when grasses contributed to less than 5\% of intake. A similar decrease in grass consumption between the spring and summer has frequently been observed in forest habitats across Europe $[24,30,48,57]$, even if the peak of grass consumption can be delayed until the summer in contexts where tender leaves on trees 
Table IV. Average Jacobs' indexes $\left(\mathrm{S}_{\mathrm{i}}\right)$ for the main vegetation components in each season. Bold characters are for selected food items, i.e. mean - s.e.m. $>0$. Italics are for avoided items, i.e. mean + s.e.m. $<0$.

\begin{tabular}{lcccc}
\hline Mean (s.e.m.) & Spring & Summer & Autumn & Winter \\
\hline Willow & $\mathbf{0 . 7 5}(\mathbf{0 . 0 9})$ & $\mathbf{0 . 9 7}(\mathbf{0 . 0 0})$ & $\mathbf{0 . 9 8}(\mathbf{0 . 0 0})$ & $-0.46(0.35)$ \\
Wild cherry & $\mathbf{0 . 2 2}(\mathbf{0 . 1 1})$ & $\mathbf{0 . 2 7}(\mathbf{0 . 1 2})$ & $\mathbf{0 . 6 5}(\mathbf{0 . 1 7})$ & $-0.54(0.38)$ \\
Chestnut tree & $0.18(0.49)$ & $\mathbf{0 . 5 8}(\mathbf{0 . 1 2})$ & $\mathbf{0 . 7 2}(\mathbf{0 . 1 0})$ & $-1.00(0.00)$ \\
Rowan & $\mathbf{0 . 4 9}(\mathbf{0 . 1 5})$ & $\mathbf{0 . 6 7}(\mathbf{0 . 0 7})$ & $-0.40(0.48)$ & $-1.00(0.00)$ \\
Common hazel & $\mathbf{0 . 1 8}(\mathbf{0 . 0 6})$ & $0.07(0.25)$ & $-0.12(0.19)$ & $-0.81(0.16)$ \\
Oak & $\mathbf{0 . 2 2}(\mathbf{0 . 1 5})$ & $-0.83(0.03)$ & $-0.53(0.19)$ & $-0.30(0.17)$ \\
Birch & $-0.36(0.32)$ & $-0.75(0.20)$ & $-0.19(0.40)$ & $-1.00(0.00)$ \\
Beech & $\mathbf{0 . 7 0}(\mathbf{0 . 1 1})$ & $-1.00(0.00)$ & $-1.00(0.00)$ & $-0.74(0.21)$ \\
All BL trees & $\mathbf{0 . 5 9}(\mathbf{0 . 0 3})$ & $\mathbf{0 . 7 1}(\mathbf{0 . 0 3})$ & $\mathbf{0 . 8 5}(\mathbf{0 . 0 1})$ & $-0.49(0.15)$ \\
\hline BL seedlings & $\mathbf{0 . 7 2}(\mathbf{0 . 0 9})$ & $\mathbf{0 . 5 9}(\mathbf{0 . 1 2})$ & $\mathbf{0 . 7 7}(\mathbf{0 . 0 6})$ & $-0.94(0.02)$ \\
\hline Coniferous trees & $-1.00(0.00)$ & $-1.00(0.00)$ & $-1.00(0.00)$ & $-0.99(0.01)$ \\
Conif. seedlings & $-1.00(0.00)$ & $-1.00(0.00)$ & $-1.00(0.00)$ & $-1.00(0.00)$ \\
\hline Dog rose & $\mathbf{0 . 8 7}(\mathbf{0 . 0 2})$ & $\mathbf{0 . 8 5}(\mathbf{0 . 0 4})$ & $\mathbf{0 . 9 6}(\mathbf{0 . 0 1})$ & $-0.98(0.02)$ \\
Broom & $-0.67(0.05)$ & $\mathbf{0 . 2 8}(\mathbf{0 . 1 8})$ & $-0.99(0.01)$ & $-0.95(0.04)$ \\
Brambles & $-0.73(0.05)$ & $-0.98(0.01)$ & $-0.73(0.02)$ & $\mathbf{0 . 2 7}(\mathbf{0 . 0 9})$ \\
Blackthorn & $-0.16(0.24)$ & $\mathbf{0 . 3 9}(\mathbf{0 . 1 6})$ & $\mathbf{0 . 4 1}(\mathbf{0 . 1 3})$ & $-1.00(0.00)$ \\
\hline Ivy & $-0.75(0.20)$ & $-0.92(0.06)$ & $-1.00(0.00)$ & $0.05(0.43)$ \\
\hline Grasses & $-0.14(0.09)$ & $-0.86(0.06)$ & $-0.62(0.08)$ & $0.66(0.05)$ \\
Forbs and Legumes & $\mathbf{0 . 5 6}(\mathbf{0 . 0 5})$ & $-0.05(0.22)$ & $\mathbf{0 . 4 8}(\mathbf{0 . 0 5})$ & $\mathbf{0 . 2 4}(\mathbf{0 . 1 0})$ \\
\hline Ferns & $-1.00(0.00)$ & $-1.00(0.00)$ & $-1.00(0.00)$ & $-1.00(0.00)$ \\
\hline BL: Broad & & &
\end{tabular}

BL: Broad-leaved (trees or seedlings).

are preferred over grass in the spring [10, 56]. In the winter, both the edible biomass (Tab. II) and the nutritive value of deciduous-leaved species (Tab. I) were strongly reduced. The hinds selected grass (Tabs. IVV) since it was a highly available and relatively "high quality" forage at that time in comparison to the forage on offer. Therefore, the net intake of digestible energy was probably increased by eating readily available grass than by searching for the higher quality but scarce forbs. Indeed, the greatest variability in the contribution of grasses to the red deer diet between habitats occurs during the winter [5]. As was the case in the present study, grasses were dominant in winter diets when a temperate climate kept study areas largely snow-free [20, 24, 26, $35,41,57]$, but deer switched towards shrubs, conifers, twigs and bark when the nutritive value of grasses dropped during the winter $[25,27,48,56]$, or because of snow cover in some continental and northern habitats $[1,5,10,30,31,34,37,43,51]$. In our study, grass consumption during the winter limited the intake drop (Tab. III) reported in other studies [56], and resulted in the dry matter intake maximisation hypothesis being valid for each animal in the winter, whereas it was rejected during the growing season. A similar seasonal pattern has been observed in a Dutch forest, in which a substantial part of the diet could be explained by rate maximisation from October through May, but 
Table V. Food items being eaten more than randomly encountered $(P<0.05)$ by each animal in the different seasons. The results are taken from comparisons between the actual diet and 1000 simulated random diets obtained by permutations of bout duration between species.

\begin{tabular}{lcccc}
\hline & Hind 001 & Hind 006 & Hind 013 & Hind 018 \\
\hline Spring & Dog rose & Dog rose & Dog rose & Non-observed \\
& Redcurrant & $\begin{array}{c}\text { Redcurrant } \\
\text { Beech } \\
\text { Mixed Forbs }\end{array}$ & $\begin{array}{c}\text { Beech } \\
\text { Willow }\end{array}$ & \\
& Rowan & Willow & Willow & Non-observed \\
Summer & Willow & Dog rose & Noge & Dog rose \\
& Willow & Willow & Nobserved & Non-observed \\
\hline Autumn & Dog rose & Birch & Grasses & Grasses \\
\end{tabular}

not in the summer when vegetation availability and quality was the highest [57]. This confirmed that although the optimal foraging theory is a useful paradigm for studying the processes involved in diet selection, it is usually unlikely to predict the choices made in a complex environment.

It should be noted that these conclusions are based on the observations of the choices made by three adult hinds, and that stags could have selected a slightly different diet because of their larger body size and the concomitant higher food requirements $[4,8$, 51]. Inter-individual differences in the botanical composition of diets have also been observed in the winter on a mountain range in Colorado [27], but few additional data are available $[17,38]$. In our study, the hinds were chosen during the preliminary period in order to account for the observed variability in consumption on broad-leaved trees. Nevertheless, the inter-individual differences in choices remained very limited (Tabs. III-V).

One of the unique aspects of this study is that a thorough investigation of the vegetation available at each season allowed us to determine which broad-leaved species were selected by the red deer and were therefore vulnerable to browsing damage. There was a marked selectivity for the willow, wild cherry and rowan tree throughout the growing season (Tab. IV). The high selectivity for the willow, together with the observations made by Dzieciolowski [10] and Homolka [30, 31] shows how attractive this species is for the red deer. However, the willow was avoided during the winter, whereas it was still consumed in other studies $[1,34]$. The highly selective consumption of broad-leaved seedlings (Tab. IV), which accounted for between $10 \%$ and $20 \%$ of daily intake when the animals entered the paddock throughout the growing season (Tab. III), suggests a high risk of damage to broad-leaved seedlings at a year-round deer density of about 15 hinds per $\mathrm{km}^{2}$. This could limit the natural regeneration of preferred broad-leaved species unless temporal and spatial variation in browsing pressure is allowed to occur [36]. Conversely, oak was never strongly selected (Tab. IV). Homolka [30] reported that oak was consumed in proportion to its abundance during the growing season. The normally high contribution of oak to the deer diet from the spring to the autumn in temperate forests $[24,35,56,57]$ may therefore be the result of its high availability rather than an actual preference by the red deer. In our study, the decrease in oak selection during the winter was less marked when compared to other broad-leaved species, which confirmed that oak nevertheless represents a resource for the red deer during the winter $[1,40]$. The 
beech was selected in the spring (Tabs. IVV) but never consumed later, thereby confirming a highly variable selection by the red deer $[10,24,30]$.

\section{CONCLUSION}

In conclusion, the hinds were highly selective, with most of their diet made of preferred species. Preferred and avoided species varied between seasons in line with plant phenology, except for conifers and ferns, which were always avoided. Hinds selected deciduous-leaved species and forbs from the spring through the autumn, switching to grass during the winter. Hinds selected grass in the winter since it was a highly available and relatively "high quality" forage at that time in comparison to the other forage on offer. Therefore, the net intake of digestible energy was probably increased by eating readily available grass than by searching for the higher quality but scarce forbs. This resulted in the dry matter intake maximisation hypothesis being valid in the winter, whereas it was rejected during the growing season. Research will now focus on a more detailed explanation of deer selectivity in relation to the nutritional characteristics of plant species, and on an analysis of the dynamics of browsing damage.

\section{ACKNOWLEDGMENTS}

We thank the INRA Departments 'Ecology of Forests, Grasslands and Freshwater' and 'Animal Physiology and Livestock Systems' for the thesis grant for P.-C. Renaud. M. Verdier from the INRA farm at Redon provided us with excellent research facilities. We also thank $\mathrm{C}$. Agreil, Ph. Ballon, P. Carrère, H. Fritz, J. Jamot, M. Meuret and D. Pépin for their scientific and methodological advice.

\section{REFERENCES}

[1] Ahlen I., A comparison between the winter feeding behaviour of the red deer and the moose, in: Blank Th. (Ed.), Proceedings of the VIth Congres of the International Union of Game Biologists, Bournemouth, UK, 1965, pp. 117-126.

[2] Aufrère J., Michalet-Doreau B., In vivo digestibility and prediction of digestibility of some by-products, in: Feeding value of byproducts and their use by beef cattle, EEC Seminar EUR 8918 EN, Melle-Gontrode, Belgium, 1983, p. 25.

[3] Bonnier G., Douin R., La Grande Flore en Couleurs de Gaston Bonnier, Belin (Ed.), Paris, 1990.

[4] Bugalho M.N., Milne J.A., Racey P.A., The foraging ecology of red deer (Cervus elaphus) in a Mediterranean environment: is a larger body size advantageous? J. Zool. (Lond.) 255 (2001) 285-289.

[5] Chen H., Ma J., Li F., Sun Z., Wang H., Luo L., Li F., Seasonal composition and quality of red deer Cervus elaphus diets in north-eastern China, Acta Theriol. 43 (1998) 77-94.

[6] Chevallier-Redor N., Verheyden-Tixier H., Verdier M., Dumont B., Foraging behaviour of red deer Cervus elaphus as a function of the relative availability of two tree species, Anim. Res. 50 (2001) 57-65.

[7] Clarke J.L., Welch D., Gordon I.J., The influence of vegetation pattern on the grazing of heather moorland by red deer and sheep. I. The location of animals on grass/heather mosaics, J. Appl. Ecol. 32 (1995) 166-176.

[8] Clutton-Brock T.H., Guinness F.E., Albon S.D., Red deer, behaviour and ecology of two sexes, University of Chicago Press, Chicago, 1982.

[9] Davies A., Baker R.D., Grant S.A., Laidlaw A.S., Sward measurement handbook, 2nd ed., Br. Grassl. Soc., Reading, 1993.

[10] Dzieciolowski R., Food of the red deer in an annual cycle, Acta Theriol. 12 (1967) 503520.

[11] Edge W.D., Marcum C.L., Olson-Edge S.L., Summer forage and feeding site selection by elk, J. Wildlife Manage. 52 (1988) 573-577.

[12] Etienne M., Non destructive methods for evaluating shrub biomass: a review, Acta Ecol. Ecol. Appl. 10 (1989) 115-128.

[13] Etzenhouser M.J., Owens M.K., Spalinger D.E., Murden S.B., Foraging behavior of browsing ruminants in a heterogeneous landscape, Lands. Ecol. 13 (1998) 55-64.

[14] Forsyth D.M., Coomes D.A., Nugent G., Hall G.M.J., Diet and diet preferences of introduced ungulates (Order: Artiodactyla) in New 
Zealand, New Zeal. J. Zool. 29 (2002) 323343.

[15] Fraser M.D., Gordon I.J., The diet of goats, red deer and South American camelids feeding on three contrasting Scottish upland vegetation communities, J. Appl. Ecol. 34 (1997) 668-686.

[16] Gebert C., Verheyden-Tixier H., Variations of diet composition of Red Deer (Cervus elaphus L.) in Europe, Mammal. Rev. 31 (2001) 189201.

[17] Gebczynska Z., Food of the Roe Deer and Red Deer in the Bialowieza Primeval Forest, Acta Theriol. 15 (1980) 89-110.

[18] Gillingham M.P., Parker K.L., Hanley T.A., Forage intake by black-tailed deer in a natural environment: bout dynamics, Can. J. Zool. 75 (1997) 1118-1128.

[19] Ginane C., Baumont R., Lassalas J., Petit M., Feeding behaviour and intake of heifers fed on hays of various quality, offered alone or in a choice situation, Anim. Res. 51 (2002) $177-$ 188.

[20] Gogan P.J.P., Barrett R.H., Elk and deer diets in a coastal prairie-scrub Mosaic, California, J. Range Manage. 48 (1995) 327-335.

[21] Groot Bruinderink G.W.T.A., Hazebroek E., Ingestion and diet composition of red deer (Cervus elaphus L.) in the Netherlands from 1954 till 1992, Mammalia 59 (1995) 187-195.

[22] Hanley T.A., A nutritional view of understanding and complexity in the problem of diet selection by deer (Cervidae), Oikos 79 (1997) 209-218.

[23] Hartley S.E., Iason G.R., Duncan A.J., Hitchcock D., Feeding behaviour of red deer (Cervus elaphus) offered Sitka Spruce saplings (Picea sitchensis) grown under different light and nutrient regimes, Funct. Ecol. 11 (1997) 348-357.

[24] Hearney A.W., Jennings T.J., Annual foods of the Red deer (Cervus elaphus) and the Roe deer (Capreolus capreolus) in the east of England, Notes Mammal. Soc. 47 (1983) 565570.

[25] Hester A.J., Gordon I.J., Baillie G.J., Tappin E., Foraging behaviour of sheep and red deer within natural heather/grass mosaics, J. Appl. Ecol. 36 (1999) 133-146.

[26] Hobbs N.T., Baker D.L., Ellis J.E., Swift D.M., Composition and quality of elk diets during winter and summer: a preliminary analysis, in: Boyce M.S., Hayden-Wing L.D. (Eds.), North American Elk: Ecology, Behav- iour and Management, WR 179, 1979, pp. 4753.

[27] Hobbs N.T., Baker D.L., Gill R.B., Comparative nutritional ecology of montane ungulates during winter, J. Wildlife Manage. 47 (1983) $1-16$

[28] Hofmann R.R., Digestive physiology of the Deer - Their morphophysiological specialisation and adaptation, in: Drew K., Fennessy P. (Eds.), Biology of deer production, Roy. Soc. N.Z. Bull. 22, 1985, pp. 393-407.

[29] Hofmann R.R., Evolutionary steps of ecophysiological adaptation and diversification of ruminants: a comparative view of their digestive system, Oecologia 78 (1989) 443457.

[30] Homolka M., Food of Cervus elaphus in the course of the year in the mixed forest habitat of the Drahanska vrchovina highlands, Folia Zool. 39 (1990) 1-13.

[31] Homolka M., Heroldová M., Native red deer and introduced chamois: foraging habits and competition in a subalpine meadow-spruce forest area, Folia Zool. 50 (2001) 89-98.

[32] Illius A.W., Gordon A.J., Modelling the nutritional ecology of ungulate herbivores: evolution of body size and competitive interactions, Oecologia 89 (1992) 428-434.

[33] Jacobs J., Quantitative measurement of food selection. A modification of the forage ratio and Ivlev's electivity index, Oecologia 14 (1974) 413-417.

[34] Jamrozy G., Winter food resources and food preferences of red deer in Carpathian forests, Acta Theriol. 25 (1980) 221-238.

[35] Jensen P.V., Food selection of the Danish red deer (Cervus elaphus L.) as determined by examination of the rumen content, Dan. Rev. Game Biol. 5/3 (1968) 1-39.

[36] Kuiters A.T., Slim P.A., Regeneration of mixed deciduous forest in a Dutch forestheathland, following a reduction of ungulate densities, Biol. Conserv. 105 (2002) 65-74.

[37] Leslie D.M. Jr., Starkey E.E., Vavra M., Elk and deer diets in old-growth forests in western Washington, J. Wildlife Manage. 48 (1984) $762-775$.

[38] Mátrai K., Kabai P., Winter plant selection by Red and Roe Deer in a Forest Habitat in Hungary, Acta Theriol. 34 (1989) 227-237.

[39] McCullagh P., Nelder J.A., Generalized Linear Models, 2nd ed., Chapman and Hall, London, 1989. 
[40] Morellet N., Guibert B., Spatial heterogeneity of winter forest resources used by deer, Forest Ecol. Manage. 123 (1999) 11-20.

[41] Morgantini L.E., Hudson R.J., Nutritional significance of wapiti (Cervus elaphus) migrations to alpine ranges in western Alberta, Canada, Arct. Alp. Res. 21 (1989) 288-295.

[42] Owen-Smith N., Cooper S.M., Nutritional ecology of a browsing ruminant, the kudu (Tragelaphus strepsiceros), through the seasonal cycle, J. Zool. (Lond.) 219 (1989) 29-43.

[43] Picard J.F., Gegout J.C., L'alimentation du cerf (Cervus elaphus) en hiver dans une forêt feuillue de plaine, Gib. Faune Sauv. 9 (1992) $127-136$

[44] Pordomingo A.J., Rucci T., Red deer and cattle diet composition in La Pampa, Argentina, J. Range Manage. 53 (2000) 649-654.

[45] Putman R.J., Moore N.P., Impact of deer in lowland Britain on agriculture, forestry and conservation habitats, Mammal. Rev. 28 (1998) 141-164.

[46] Renaud P.-C., Verheyden-Tixier H., Dumont B., Damage to saplings by red deer (Cervus elaphus): effect of foliage height and structure, Forest Ecol. Manage. 181 (2003) 31-37.

[47] Said S., Pellerin M., Guillon N., Fritz H., Forage availability assessment for ecological studies of browsers in deciduous woodlands, Eur. J. Wildlife Res. (2005) accepted.

[48] Saint-Andrieux Ch., Klein F., Roe and red deer diet in relation to damage to silver fir, in: Thomaidis C., Kypridemos N. (Eds.), Proceedings of the XXIVth Congres of the International Union of Game Biologists, Thessaloniki, Greece, 2002, pp. 409-422.
[49] Semiadi G., Barry T.N., Muir P.D., Hodgson J., Dietary preferences of sambar (Cervus unicolor) and red deer (Cervus elaphus) offered browse, forage legume and grass species, J. Agric. Sci. (Camb.) 125 (1995) 99-107.

[50] Shipley L.A., Blomquist S., Danell K., Diet choices made by free-ranging moose in northern Sweden in relation to plant distribution, chemistry, and morphology, Can. J. Zool. 76 (1998) 1722-1733.

[51] Staines B.W., Crisp J.M., Parish T., Differences in the quality of food eaten by red deer (Cervus elaphus) stags and hinds in winter, $\mathrm{J}$. Appl. Ecol. 19 (1982) 65-77.

[52] Statistical Analysis System, SAS/STAT User's Guide, Version 8, SAS Institute Inc., Cary, NC, USA, 1999.

[53] Szemethy L., Mátrai K., Katona K., Orosz S., Seasonal home range shift of red deer hinds, Cervus elaphus: are there feeding reasons? Folia Zool. 52 (2003) 249-258.

[54] Thompson M.J., Henderson R.E., Elk habituation as a credibility challenge for wildlife professionals, Wildlife Soc. Bull. 26 (1998) 477-483.

[55] Tixier H., Duncan P., Scehovic J., Yani A., Gleizes M., Lila M., Food selection by European roe deer (Capreolus capreolus): effects of plant chemistry, and consequences for the nutritional value of their diets, J. Zool. (Lond.) 242 (1997) 229-245.

[56] Van de Veen H.E., Food selection and habitat use in the red deer (Cervus elaphus L.), Ph.D. Thesis, University of Groningen, The Netherlands, 1979.

[57] Van Wieren S.E., Do large herbivores select a diet that maximizes short-term energy intake rate? Forest Ecol. Manage. 88 (1996) 149156. 